\title{
PENGEMBANGAN MODUL BERBASIS REALISTIC MATHEMATICS EDUCATION (RME) PEMBELAJARAN MATEMATIKA KELAS V SDN 020 BALIKPAPAN TENGAH
}

\author{
Sugeng $^{1}$, Azainil $^{1}$, Nuryanto $^{2}$ \\ ${ }^{1}$ Universitas Mulawarman, ${ }^{2}$ SDN 020 Balikpapan Tengah \\ sugeng@pkip.unmul.ac.id, azainil@.fkip.unmul.ac.id, nuryanto20sd@gmail.com
}

\begin{abstract}
Abstrak
Penelitian ini bertujuan untuk menghasilkan dan mengembangkan modul berbasis Realistic Mathematics Education (RME) pembelajaran matematika serta untuk mengetahui kelayakan dan efektifitas penggunaan modul berbasis Realistic Mathematics Education (RME). Jenis penelitian ini merupakan penelitian dan pengembangan dengan pendekatan kualitatif dan kuantitatif. Subjek ujicoba terdiri dari ahli desain modul, ahli materi, praktisi/guru senior yang membidangi keilmuan matematika, dan siswa kelas V SDN.020 Balikpapan Tengah. Tingkat kelayakan modul menunjukan : hasil analisis dari ahli media pertama diperoleh 83.33 masuk dalam kategori sangat layak, hasil analisis dari ahli materi pertama diperoleh 80.88 masuk dalam kategori layak, hasil analisis dari ahli materi kedua diperoleh 82.35 masuk dalam kategori sangat layak, hasil analisis dari ahli praktisi/guru senior diperoleh 92.04 masuk dalam kategori sangat layak. Uji efektifivas penggunaan modul dinilai berdasarkan peningkatan nilai pretest dan posttest pada siswa. efektifivitas penggunaan modul digunakan Uji Statistik yaitu Uji $t$ Berpasangan. Pada pengujian asumsi data berdistribusi normal, data memenuhi distribusi normal apabila $p$ value $>0,05$ (taraf signifikansi). Berdasarkan tabel One Sample Kolmogorov Smirnov Test, didapatkan p value pada pretest sebesar 0,467 >0,05 dan posttest sebesar 0,114 >0,05. Oleh karena itu, dapat disimpulkan bahwa data pretest dan posttest memenuhi asumsi distribusi normal. Karena data memenuhi asumsi distribusi normal, maka Uji $t$ Berpasangan dapat digunakan. Berdasarkan tabel Paired Sample Test pada 30 sampel dengan taraf signifikansi 0,05 , didapatkan $p$ value sebesar $0,000<0,05$. Artinya $H o$ ditolak, terdapat perbedaan nilai pretest dan posttest secara signifikan. Oleh karena itu dapat disimpulkan bahwa penggunaan modul efektif digunakan pada siswa.
\end{abstract}

Kata Kunci: Pengembangan, Modul RME, Matematika,

\section{PENDAHULUAN}

Pendidikan merupakan salah satu upaya meningkatkan kualitas sumber daya manusia. Kesadaran tentang pentingnya pendidikan telah mendorong berbagai upaya dan perhatian pada bidang pendidikan. Pendidikan juga mengalami perubahan dan perbaikan seiring dengan perkembangan di segala asfek kehidupan. Upaya perbaikan dan perubahan ini bertujuan membawa mutu pendidikan kearah yang lebih baik. Suprihatiningrum (2016:112) mengemukakan bahwa pelaksanaan pendidikan di sekolah selalu berkaitan dengan kegiatan pembelajaran. Oleh karena itu dalam kegiatan pembelajaran, pemilihan bahan ajar merupakan salah satu faktor yang dapat mempengaruhi kualitas pembelajaran. Bahan ajar yang dipilih dapat dipakai untuk mencapai tujuan atau kompetensi yang ingin dicapai.

Pengembangan bahan ajar harus kita sesuaikan dengan karakteristik sasaran dan pemecahan masalah belajar yang ada disekolah. Bahan ajar khususnya buku lebih sering digunakan guru untuk menunjang materi dalam proses pembelajaran. Seringkali bahan belajar yang ada dari hasil pengembangan orang lain terkadang tidak sesuai untuk siswa kita. Dengan demikian bahan ajar sebaiknya dibuat sendiri oleh guru agar lebih menarik serta lebih kontekstual dengan situasi dan kondisi sekolah maupun lingkungan sosial budaya siswa. Bahan ajar yang didesain secara lengkap dan memadai akan mempengaruhi suasana pembelajaran sehingga proses belajar yang terjadi pada siswa menjadi lebih optimal dan sekaligus dapat berperan sebagai bahan belajar mandiri (Depdiknas, 2008)

Pentingnya sebuah bahan ajar dalam proses pembelajaran ditemukan dalam penelitian Shokifatul Azkiyah (2013) dikatakan bahwa banyak bahan ajar yang tersedia dipasaran, termasuk buku paket dan buku ajar yang telah disusun oleh Depdiknas. Namun tetap dibutuhkan suatu pengembangan buku ajar demi memenuhi dan melengkapi upaya kebutuhan pembelajaran bagi siswa, hal ini sesuai dengan tujuan kompetensi yang akan dicapai siswa.

Hasil studi pendahuluan di SDN 020 Balikpapan Tengah, penggunaan beberapa buku pelajaran yang telah tersedia dari sekolah cenderung membuat guru memilih dan mengkolaborasi buku yang satu dengan yang lainnya. Penggunaan buku pelajaran yang ada di sekolah masih menekankan pada penguasaan konsep dengan cara menuntut siswa untuk menghafalnya. Inilah salah satu hal yang dapat menyebabkan guru tidak membuat bahan ajar yang disesuaikan dengan karakteristik sasaran dan tuntutan pemecahan masalah belajar siswanya. Akibatnya berdampak pada hasil belajar siswa yang hanya mencapai rata-rata nilai 65 dari standar nilai Kriteria Ketuntasan Minimal (KKM) yang telah ditentukan, khususnya pada mata pelajaran matematika. 
Banyak metode dan terobosan baru dari penelitipeneliti sebelumnya untuk mengatasi masalah tersebut, salah satunya melalui pendekatan Realistic Mathematics Education (RME) yaitu sebuah pendekatan pembelajaran matematika yang dapat mengubah mind set dan sudut pandang siswa dari matematika yang abstrak menjadi matematika yang dekat dengan kehidupannya, kontekstual, realistis dan menyenangkan. Hal ini sejalan dengan pernyataan Freudenthal dalam Hadi (2017:8) yang mendefinisikan bahwa "Mathematic is human activity" matematika merupakan aktivitas insani dan harus dikaitkan dengan realitas. Realistic Mathematics Education (RME) menggabungkan pandangan tentang apa itu matematika, bagaimana siswa belajar matematika, dan bagaimana matematika harus disajikan. Freudenthal berkeyakinan bahwa siswa tidak boleh dipandang sebagai "passive recevers of ready-made mathematics" penerima pasif matematika yang sudah jadi atau diolah .

Merujuk pada hasil penelitian Marhamah, Zulkardi, dan Aisyah (2014) yaitu pengembangan materi ajar dengan pendekatan PMRI (Pendidikan Matematika Realistik Indonesia), berdasarkan proses pengembangan diperoleh bahwa prototype materi ajar yang dikembangkan efektif meningkatkan aktivitas belajar siswa. Berdasarkan proses pengembangan diperoleh juga bahwa prototype materi ajar yang dikembangkan telah memiliki potensial efek terhadap kemampuan siswa.

Temuan yang sama juga dilaporkan dalam penelitian yang dilakukan La Ose (2017) di provinsi Gorontalo dengan mengambil sampel siswa siswi SMP Negeri 1 kelas VIII ditemukan pengaruh yang positif terhadap hasil belajar siswa pada materi luas permukaan dan volume balok dengan menggunakan pendekatan Pendidikan Matematika Realistik (PMR) dengan nilai ketuntasan $83 \%$.

Hasil yang kurang lebih sama pada pengembangan materi ajar matematika yang dilakukan oleh Jusmanidar (2017) dalam penelitiannya yang menjadikan meningkatnya hasil belajar siswa melalui pendekatan matematika realistik. Dengan pendekatan matematika realistik akan memberikan kesempatan kepada siswa untuk menemukan dan mengkonstruksikan kembali konsep-konsep matematika sehingga siswa mempunyai konsep pengertian yang kuat. Dikatakan pula bahwa hasil pembelajaran matematika tergantung pada bagaimana guru melaksanakan pembelajaran. Guru harus menciptakan pembelajaran yang menyenangkan bagi siswa, salah satu cara yaitu dengan menerapkan pendekatan matematika realistik. Oleh sebab itu perlu dikembangkan suatu pembelajaran yang tidak membosankan dan membuat siswa lebih tertarik, dengan cara menciptakan lingkungan belajar yang dekat dengan dunia nyata.

Ketiga temuan yang dilakukan pada pengembangan bahan ajar pada mata pelajaran matematika semua menggunakan pendekatan matematika realistik, karena Realistic Mathematics Education (RME) dinilai paling tepat digunaan dalam pembelajaran matematika yang lebih menekankan realistas dan lingkungan sebagai titik awal dari pembelajaran, selain itu Realistic Mathematics Education (RME) dianggap sangat cocok digunakan karena memiliki karakteristik dan prinsip yang memungkinkan siswa dapat berkembang secara optimum, seperti kebebasan siswa untuk menyampaikan pendapat dan adanya masalah kontekstual yang dapat mengkaitkan konsep matematika dengan kehidupan nyata.

Mengacu pada uraian diatas peneliti mencoba untuk menggunakan bahan ajar modul matematika melalui pendekatan Realistic Mathematics Education (RME) khususnya pada siswa kelas V di Sekolah Dasar Negeri 020 Balikpapan Tengah, dengan tujuan untuk mengetahui: (1) Pengembangan modul matematika dengan pendekatan Realistic Mathematics Education (RME) pada materi pecahan kelas V SDN 020 Balikpapa Tengah, (2) Kelayakan modul matematika dengan pendekatan Realistic Mathematics Education (RME) pada materi pecahan kelas V SDN 020 Balikpapan Tengah, (3) Efektivitas penggunaan modul matematika dengan pendekatan Realistic Mathematics Education (RME) pada materi pecahan kelas V SDN 020 Balikpapan Tengah.

\section{METODE}

Penelitian ini merupakan penelitian pengembangan (Research and Development) yaitu penelitian untuk mengembangkan produk sampai dengan menghasilkan sebuah produk yang layak digunakan peserta didik. Produk yang dikembangkan dalam penelitian ini adalah modul matematika dengan menggunakan pendekatan Realistik Matematic Education (RME) materi pecahan pada siswa kelas $\mathrm{V}$ di SD Negeri 020 Balikpapan. Pengembangan modul matematika ini menggunakan model ASSURE dengan tahapan sebagai berikut: 1) analisis pembelajar (analyze learners), 2) obyek tujuan (state objectives), 3) memilih metode, media dan bahan (select methods, media and materials), 4) memanfaatkan media dan materi (utilize media, and materials), 5) pertisipasi siswa (require learner participation), 5) evaluasi (evaluateand revise). 
Uji coba produk dalam penelitian pengembangan ini meliputi 1) desain rancangan uji coba, 2) subjek uji coba, 3) instrument pengumpulan data, dan 4) teknik analisis data. Uji coba dilakukan dalam beberapa tahap yakni: 1) produk divalidasi oleh ahli desain modul, ahli materi dan praktisi/guru senior. 2) uji coba kelompok kecil menggunakan sampel 9 siswa, dengan kriteria prestasi belajar yang berbeda yaitu tiga siswa yang memiliki prestasi belajar tinggi, tiga siswa yang memiliki prestasi belajar sedang, dan tiga siswa yang memiliki prestasi belajar rendah 3) Uji coba lapangan diambil sampel dari semua siswa kelas V.

Instrumen yang digunakan dalam peneilitian pengembangan ini adalah angket dan tes hasil belajar siswa. Angket digunakan untuk mengumpulkan data hasil validasi ahli desain modul, ahli materi, dan praktisi/guru senior, hasil dari uji coba kelompok kecil, hasil dari uji coba lapangan/semua siswa. Sedangkan tes hasil belajar digunakan untuk mengetahui efektifitas produk dari hasil belajar sebelum menggunakan modul dan sesudah menggunakan modul matematika dengan pendekatan $R M E$.

Teknik analisis data yang digunakan dalam penelitian ini yaitu teknik analisis data deskriptif kualitatif dan teknik analisis data desktiptif kuantitatif. Teknik analisis data kualitatif digunakan untuk mengolah data hasil uji coba dari ahli desain modul, ahli materi, praktisi/guru senior, peserta didik kelompok kecil, uji lapangan. Teknik analisis deskriptif kuantitatif digunakan untuk mengolah data dari angket dalam bentuk deskriptif presentase.

Rumus yang digunakan adalah:

Persentasi komponen $(\mathrm{P})=$ $\underline{\text { Jumlah skor komponen hasil penelitian }(S)} \times 100 \%$ Jumlah skor maksimum $(N)$

Hasil persentasi data dikonversikan berdasarkan kriteria "sangat layak, layak, cukup layak, dan tidak layak". Presentase yang telah diperoleh kemudian ditranformasikan ke dalam tabel agar pembacaan hasil penelitian menjadi mudah. Penentuan kriteria kualitatif dengan cara sebagai berikut: 1) Menentukan presentase skor ideal (skor maksimum) $=100 \%, 2$ ) Menentukan presentase skor terendah (skor minimum) $=25 \%, 2$ )

Menentukan rentang $=100 \%-25 \%=75 \%, 3$ ) Menentukan banyak kelas interval yang diperlukan $=4$ (sangat layak, layak, cukup layak, dan kurang layak) untuk kelayakan modul, 5) Menentukan panjang kelas interval (p)

$\mathrm{p}=\frac{\text { rentang }}{\text { banyak kelas }}$

$\mathrm{p}=\frac{75 \%}{4}=18,75 \%$

diambil $p=19$ (dengan pembulatan).

Perhitungan diatas memperoleh hasil $\mathrm{p}=19$ dan melulai dengan bawah kelas interval 25\%, maka kelas pertama berbentuk $25 \%$ - $43 \%$, kelas kedua $44 \%$ - $62 \%$, kelas ketiga $63 \%$ - $81 \%$ dan data kelas keempat $82 \%$ $100 \%$. Dapat dibuat tabel kriteria hasil perolehan skor kelayakan (Penilaian validasai para ahli) berikut ini:

Tabel. Kriteria peroleh skor

\begin{tabular}{|c|c|c|c|}
\hline No & Tingkat Pencapaian & Kualifikasi & Keterangan \\
\hline 1 & $82 \%-100 \%$ & Sangat layak & Tidak perlu direvisi \\
\hline 2 & $63 \%-81 \%$ & Layak & Tidak perlu direvisi \\
\hline 3 & $44 \%-62 \%$ & Cukup layak & Revisi \\
\hline 4 & $25 \%-43 \%$ & Kurang layak & Revisi \\
\hline
\end{tabular}

\section{HASIL DAN PEMBAHASAN}

Tahap pengembangan modul memilih model ASSURE dengan beberapa pertimbangan diantaranya yang didapat dari hasil studi pendahuluan di SDN 020 Balikpapan Tengah yaitu : (1) analisis pebelajar (Analisis Learner) dilihat dari karakteristik umum usia yang rata-rata usia siswa kelas V kurang lebih $10-12$ tahun, dimana pada usia tersebut siswa sudah dapat membuat kesimpulan dari sesuatu pada situasi nyata atau dengan menggunakan benda konkret, dan mampu mempertimbangkan dua aspek dari situasi nyata secara bersama-sama (Thobroni, 2016:81). Gaya belajar
(Learning Styles) dari hasil pengamatan kegiatan pembelajaran, siswa memiliki gaya belajar visual dan kinestetik. Dari gaya belajar visual siswa lebih senang melihat dan mendemonstrasikan sesuatu dibanding hanya mendengar, dari gaya belajar kinestetik siswa terlihat lebih menyukai belajar dengan melakukan praktik langsung atau dengan obyek nyata sebagai alat bantu. Mengevaluasi kemampuan awal pembelajar (Entry Competency), pada mata pelajaran matematika khususnya materi pecahan sebenarnya telah siswa dapatkan sejak duduk di kelas IV, namun sampai siswa duduk dikelas $\mathrm{V}$ masih juga siswa merasa kesulitan 
terhadap materi pecahan tersebut. hal ini diperkuat dari hasil studi pendahuluan yang dilakukan peneliti terhadap guru kelas IV di SDN 020 Balikpapan Tengah. Perolehan nilai rata-rata yang diperoleh siswa khususnya pada ulangan harian materi pecahan hanya $50 \%$ dari jumlah siswa yang ada. Ini menunjukan bahwa kemampuan awal siswa khususnya pada materi pecahan masih terbilang rendah. (2) Menyatakan tujuan (State Standars and Objectives), dalam standar pembelajaran jelas dapat digunakan untuk mengevaluasi efektivitas keberhasilan proses pembelajaran dan digunakan sebagai pedoman dalam kegiatan pembelajaran. (3) Memilih metode, media dan bahan (Select Strategis, Medias and Materials) dalam pembelajaran merupakan salah satu hal yang sangat menunjang keberhasilan dalam satu proses kegiatan pembelajaran. (4) Penggunaan media dan bahan ajar (Utilize, Media And Materials) dalam kegiatan pembelajaran lebih bervariasi dan disesuaikan dengan penggunaan bahan ajar, (5) Partisipasi siswa (Require Learner Participation) dalam pembelajaran sangat diharapkan. Dengan kegiatan praktik didalam pembelajaran siswa akan terlibat secara langsung, dan siswa dapat leluasa mengeskplor kemampuan dan daya pikir mereka. (6) Evaluasi (Evaluate) dalam kegiatan pembelajaran dilakukan pembelajar selesai. Hal ini dilakukan bertujuan untuk mengukur keefektifan pembelajaran yang telah dilakukan dan ketuntasan hasil belajar yang telah siswa lakukan.

Perencanaan pengembangan modul disesuaikan dengan karakteristik sasaran dan pemecahan masalah belajar yang ada disekolah. Oleh karena itu sebelum dilakukan pengembangan produk peneliti terlebih dahulu mengawali dengan mencari data melalui studi lapangan dan studi literatur yang akan digunakan sebagai bahan dalam perencanaan pengembangan produk yang diharapkan.

Kelayakan dalam pengembangan suatu produk sangatlah penting. Sebelum suatu produk digunakan secara luas, pastinya kelayakan uji coba produk sangat perlu dilakukan dengan tujuan untuk mengetahui apakah produk tersebut layak digunakan atau tidak. Dalam penelitian pengembangan ini, peneliti merancang suatu produk berupa modul pembelajaran matematika berbasis Realistic mathematics Education (RME) materi pecahan pada siswa kelas V, sebelum modul digunakan secara luas peneliti melakukan uji coba modul dengan melibatkan beberapa para ahli sebagai validator modul. beberapa para ahli yang digunakan yaitu :

\section{a. Validator ahli desain modul}

Ahli desain modul yang peneliti gunakan sebagai validator modul matematika berbasis Realistic mathematics Education (RME) materi pecahan adalah ibu Dr. herliani, M.Pd beliau merupakan salah satu dosen di Universitas Mulawarman Samarinda yang memilki keahlian dalam bidang mendesain modul. validasi ahli desai modul dilakukan 2 kali di kampus Universitas Mulawarman Samarinda dengan memuat beberapa aspek penilaian. Dari hasil validasi ahli desain modul dianalsis dan diperoleh rata-rata berjumlah 83.33 dan masuk dalam kategori "Sangat layak".

b. Validator ahli materi modul

Ahli materi modul yang peneliti gunakan sebagai validator modul matematika berbasis Realistic mathematics Education (RME) materi pecahan adalah Ibu Mardiana, S.KM, M.Kes (ahli materi modul pertama) beliau merupakan salah satu dosen di kampus UMKT (Universitas Muhammadiyah Kalimantan Timur) Samarinda dan Ibu Dr. Rusdiana, M.Pd (ahli materi modul kedua) beliau merupakan salah satu dosen ahli matematika di Universitas Mulawarman Samarinda yang memiliki keahlian pada materi modul. Validasi ahli materi dilakukan 2 kali di kampus Universitas Muhammadiyah Kalimantan Timur Samarinda, dengan menggunakan 3 aspek penilaian yaitu aspek kelayakan isi, aspek penyajian, dan aspek pendekatan Realistic Mathematics Education (RME). Dari hasil validasi ahli materi modul pertama dianalsis dan diperoleh rata-rata berjumlah 80.88 dan masuk dalam kategori "Layak". Dari hasil validasi ahli materi modul kedua dianalsis dan diperoleh rata-rata berjumlah 82.35 dan masuk dalam kategori "Sangat Layak".

c. Validator praktisi/guru senior

Ahli dari praktisi/guru senior yang peneliti gunakan adalah salah satu guru senior yang ada di SDN 020 Balikpapan Tengah yaitu ibu Nenty, S.Pd selain sebagai guru senior beliau juga sebagai guru yang mempunyai bidang keilmuan matematika di sekolah tersebut. validasi praktisi/guru senior dilakukan sebanyak 2 kali di SDN 020 balikpapan Tengah dengan menggunakan 4 aspek penilaian yaitu aspek kelayakan isi, aspek kelayakan penyajian, aspek penilaian bahasa, dan aspek pendekatan Realistic Mathematics Education $(R M E)$. Dari hasil validasi praktisi/guru senior dianalsis dan diperoleh rata-rata berjumlah 92.04 dan masuk dalam kategori "Sangat Layak".

Dari hasil penilaian para ahli desain modul, ahli materi modul, dan praktisi/guru senior, setelah dianalsis dapat disimpulkan bahwa modul matematika berbasis Realistic mathematics Education (RME) materi pecahan yang dikembangkan dengan memuat beberapa 
aspek penilaian dan memperoleh rata-rata yang masuk dalam kateragori "Sangat Layak" dapat diuji cobakan kepada seluruh siswa kelas V di SDN 020 Balikpapan Tengah.

Tahap akhir setelah mengetahui kelayakan modul yaitu mengetahui efektivitas modul tersebut. Sangat diharapkan modul yang telah di validasi dari beberapa para ahli dan dikatakan sangat layak akan menghasilkan suatu modul yang efektif digunakan pada siswa kelas V di SDN 020 Balikpapan Tengah. Untuk mengetahui hal tersebut selanjutnya peneliti melakukan uji efektivitas penggunaan modul pada kelompok besar yang terdiri dari siswa kelas $\mathrm{V}$ dengan jumlah 30 siswa. Uji efektivitas dilakukan dengan membandingkan hasil belajar siswa sebelum menggunakan modul (freetest) dan hasil belajar siswa setelah menggunakan modul (posttest). Adapun hasil belajar siswa sebelum menggunakan modul diperoleh rata-rata sejumlah 63.33 (perolehan nilai dapat dilihat pada tabel 4.11), dan hasil belajar siswa setelah menggunakan modul diperoleh rata-rata sejumlah 84.17 (perolehan nilai dapat dilihat pada tabel 4.13). dilihat dari ketuntasan kriteria minimum yang sekolah tetapkan, maka persentasi ketuntasan diatas rata-rata dengan perolehan nilai $84 \%$. Hal ini membuktikan bahwa penggunaan modul matematika berbasis Realistic mathematics Education ( $R M E$ ) materi pecahan yang telah diujicobakan pada siswa kelas V di SDN 020 Balikpapan Tengah sangat efektif dalam meningkatkan hasil belajar siswa.

Mengukur efektifivitas penggunaan modul juga digunakan uji statistik yaitu uji-t berpasangan. Sebelum melakukan uji- $t$ Berpasangan, terlebih dahulu dilakukan pengujian normalitas data. Apabila data berdistribusi normal, maka uji- $t$ Berpasangan dapat digunakan untuk menilai efektivitas, tetapi apabila data tidak berdistribusi normal, maka digunakan alternative uji Wilcoxon. Terbukti dari pengujian asumsi data berdistribusi normal, data memenuhi distribusi normal apabila $p$ value $>0,05$ (taraf signifikansi). Berdasarkan tabel one sample kolmogorov smirnov test, didapatkan $p$ value pada pretest sebesar $0,467>0,05$ dan posttest sebesar $0,114>0,05$ (data dapat diliat pada lampiran). Oleh karena itu, dapat disimpulkan bahwa data pretest dan posttest memenuhi asumsi distribusi normal, karena data memenuhi asumsi distribusi normal, maka uji-t berpasangan dapat digunakan.

Pengujian menggunakan uji-t berpasangan, pada taraf signifikansi 0,05 , terdapat hipotesis sebagai berikut yaitu $H O$ tidak terdapat perbedaan nilai pretest - posttest secara signifikan, H1 terdapat perbedaan nilai pretest - posttest secara signifikan. Pada pengujian menggunakan uji-t berpasangan, pada taraf signifikansi
0,05 , terdapat kriteria pengujian hipotesis sebagai berikut yaitu $H O$ ditolak apabila $p$ value $<0,05$ (terdapat perbedaan nilai pretest - posttest secara signifikan), $H O$ diterima apabila $p$ value $>0,05$ (tidak terdapat perbedaan nilai pretest - posttest secara signifikan).

Berdasarkan tabel paired sample test pada 30 sampel dengan taraf signifikansi 0,05 , didapatkan $p$ value sebesar $0,000<0,05$. Artinya $H 0$ ditolak, terdapat perbedaan nilai pretest dan posttest secara signifikan. Oleh karena itu dapat disimpulkan bahwa penggunaan modul efektif digunakan pada siswa karena berdasarkan hasil pengujian secara statistik pada nilai pretest posttest siswa terdapat perbedaan secara signifikan.

\section{PENUTUP}

Proses pengembangan modul matematika dengan menggunakan pendekatan Realistic Mathematics Education (RME) pada siswa kelas V di SDN 020 Balikpapan Tengah dimulai dengan melakukan analisis kebutuhan, pengumpulan data, desain produk, validasi desain, revisi desain, uji coba produk, revisi produk, uji coba pemakaian, revisi produk dan produksi massal sehingga dapat menghasilkan produk yang layak digunakan dalam pembelajaran. Hasil media modul pembelajaran dikemas dalam bentuk buku modul.

Kelayakan media pembelajaran pengembangan modul matematika berbasis Realistic Mathematics Education (RME) dianalisis berdasarkan instrumen penilaian dari para ahli media, ahli materi dan praktisi/guru senior dari sekolah peneliti. Hasil validasi dari ahli media terdapat 1 asfek kegrafikan dengan 4 indikator penilaian dengan hasil nilai rata-rata 83.33 dan masuk dalam kategori " Sangat Layak". Hasil validasi dari ahli materi pertama terdapat 3 aspek kelayakan isi, aspek kelayakan penyajian, dan penilaian pendekatan Realistic Mathematics Education (RME) dengan hasil nilai rata-rata berjumlah 80.88 masuk dalam kategori "Layak". Hasil validasi dari ahli materi kedua terdapat 3 aspek kelayakan isi, aspek kelayakan penyajian, dan penilaian pendekatan Realistic Mathematics Education (RME) dengan hasil nilai ratarata berjumlah 82.35 masuk dalam kategori "Sangat Layak". Hasil validasi dari praktisi/guru senior terdapat 4 aspek yaitu asfek kelayakan isi, aspek kelayakan penyajian, aspek penilaian bahasa dan penilaian pendekatan Realistic Mathematics Education (RME) dengan perolehan nilai rata-rata berjumlah 92.04 dan masuk dalam kategori "Sangat Layak".

Uji coba produk diperoleh respon/tanggapan siswa dari media pembelajaran pengembangan modul 
matematika berbasis Realistic Mathematics Education (RME) dianalisis dari kuisioner responden skala besar sejumlah 30 siswa. Responden di minta untuk memberikan penilaian respon, saran serta komentar terhadap media pembelajaran. Hasil analisis respon dari siswa mempunyai nilai dengan jumlah 1081 dengan nilai rata-rata sebesar 90.08 , ini menunjukan bahwa respon dari siswa sangat baik dan siswa juga merasa tertarik dalam mengikuti pelajaran khususnya pada mata pelajaran matematika.

Uji efektivitas Berdasarkan tabel Paired Sample Test pada 30 sampel dengan taraf signifikansi 0,05 , didapatkan $\mathrm{p}$ value sebesar $0,000<0,05$. Artinya $\mathrm{H} 0$ ditolak, terdapat perbedaan nilai pretest dan posttest secara signifikan. Oleh karena itu dapat disimpulkan bahwa penggunaan modul efektif digunakan pada siswa karena berdasarkan hasil pengujian secara statistic pada nilai pretest - posttest siswa terdapat perbedaan secara signifikan.

Melalui penelitian pengembangan ini modul berbasis Realistic Mathematics Education (RME) pembelajaran matematika materi pecahan diharapkan dapat bermanfaat dalam proses pembelajaran khususnya pembelajaran matematika.

\section{REFERENSI}

Azkiyah S. 2013. Pengembangan Buku Ajar Matematika Materi Pecahan Berbasis Pendekatan Pendidikan Matematika Realistik Indonesia (PMRI) untuk SD/MI [Tesis]. Malang: Universitas Islam Negeri Maulana Malik Ibrahim.
Departemen Pendidikan Nasional. 2008. Penulisan Modul. Depdiknas, Jakarta.

Hadi, Sutarto. 2017. Pendidikan Matematika Realistik (edisi Revisi). PT.Raja Grafindo Persada, Jakarta.

Jusmanidar. (2017).Meningkatkan Hasil belajar Siswa pada Operasi Hitung melalui Pendekatan Matematika Realisitik.. JPPI (Jurnal Penelitian Pendidikan Indonesia.) https://doi.org/10.2921/02017104

Marhamah, M., Zulkardi, Z., \& Aisyah, N. (2014). Pengembangan Materi Ajar Pecahan dengan Pendekatan PMRI di SD Negeri 21Palembang. Jurnal Pendidikan Matematika.

https://doi.org/10.22342/jpm.5.2.584

Ode, L. (2017).Pengembangan Perangkat Pembelajaran dengan Pendekatan PMR untuk Meningkatkan Hasil Belajar Siswa. Jurnal matematika kreatif-inovatif. https://doi.org/10.15294/kreano.v8i2.6981

Sugiono. 2016. Metode Penelitian Pendidikan (Pendekatan Kuantitatif, Kualitatif dan $R \& D)$. Alfabeta, Bandung.

Suprihatiningrum, Jamil. 2016. Strategi Pembelajaran Teori dan Aplikasi. Ar-Ruzz Media, Yogyakarta.

Thobroni, M. 2016. Belajar dan Pembelajaran. Ar-Ruzz Media, Yogyakarta. 